\title{
Efektivitas E-Government melalui Banserv pada Kota Bandung
}

\author{
Oleh: Lukman Munawar Fauzi ${ }^{1}$, Siti Nurul Ajizah ${ }^{2}$, Dody Kurnia ${ }^{3}$, Susi Yulianti ${ }^{4}$ \\ Dosen Jurusan Ilmu Pemerintahan FISIP Unjani \\ e-Mail : lukmanulhakim.unjani@gmail.ac.id
}

\begin{abstract}
Abstrak
Sistem politik Indonesia sudah dinamis dan mampu mengikuti perkembangan zaman. Hal tersebut terbukti dengan program e-government, yaitu penggunaan teknologi informasi dan komunikasi dalam penyelenggaraan pemerintahan untuk meningkatkan kinerja dan hubungan antar pemerintah dengan pihak-pihak lain. Salah satu jenis e-government adalah Government To Citizen (G2C), yaitu penyampaian informasi dan layanan publik secara searah dari pemerintah ke masyarakat. Bagian dari Government To Citizen adalah website resmi pemerintah sebagai media penyampaian informasi pemerintah kepada masyarakat yang mulai diterapkan di setiap daerah Indonesia salah satunya Kota Bandung yaitu website resmi Kota Bandung. Namun, pada kenyataannya penyampaian informasi melalui website belum efektif. Hal tersebut diketahui dari penelitian yang ditulis dalam sebuah makalah ilmiah berjudul “Efeketivitas E-Government melalui Banserv Pada Kota Bandung”. Rumusan masalah pada penelitian ini, yaitu bagaimana cara untuk meningkatkan efektivitas website resmi Kota Bandung dalam mengoptimalkan program e-government?. Penelitian ini dilakukan dengan penyebaran angket kepada masyarakat Kota Bandung. Pada hasil penelitian yang telah dilakukan, ditemukan masalah, yaitu sebagian masyarakat tidak mengetahui website resmi Kota Bandung, bahkan masyarakat yang mengetahui tidak suka mengaksesnya, padahal website resmi Pemerintah Kota Bandung dapat memudahkan masyarakat untuk mendapatkan informasi lebih banyak. Hal tersebut menunjukan bahwa program e-government Kota Bandung pada salah satu media internet, yaitu website masih belum efektif, maka informasi tidak tersampaikan kepada masyarakat. Maka, diperlukan sebuah solusi untuk menyelesaikan permasalahan tersebut, yaitu melaui BanServ. BanServ (Bandung Service), adalah sebuah layanan notifikasi kepada masyarakat melaui handphone, yaitu adanya notifikasi berupa pesan singkat. Metode BanServ ini dapat menjadi salah satu alternatif solusi yang membantu pemerintah dalam penyampaian informasi.
\end{abstract}

Kata Kunci: E-Government, Website, Kota Bandung.

\section{Efektivitas E-Government melalui Banserv pada Kota Bandung}

\section{PENDAHULUAN}

\section{Latar Belakang}

Saat ini, sistem politik Indonesia

sudah dinamis dan mampu mengikuti perkembangan zaman teknologi. Di

Indonesia Teknologi Informasi dan

Komunikasi (TIK) telah berkembang sangat jauh dan merevolusi cara hidup kita, baik cara bekerja, cara berbisnis, dan lain 
sebagainnya. Era informasi memberikan ruang lingkup yang sangat besar untuk mengorganisasikan segala kegiatan melalui cara baru, inovatif, instan, tansparan, akurat, tepat waktu, lebih baik, memberikan kenyamanan yang lebih dalam mengelola dan menikmati kehidupan dengan teknologi informasi dan komunikasi semua proses kerja dan konten akan ditransformasikan dari fisik dan statis (menjadi digital, mobile, virtual dan personal). Kemajuan sistem politik Indonesia yang dinamis dan mampu mengikuti perkembangan zaman ini ditandai dengan adanya program e-government. Program e-government di Indonesia didasari oleh Instruksi Presiden Republik Indonesia Nomor 3 Tahun 2003 Tentang Kebijakan dan Strategi Nasional Pengembangan $E$ Government.

Menurut Josua M. Sinambela definisi E-Government disetiap daerah/negara dan komunitas bisa beragam salah satunya di New Zealand bahwa $e$ government adalah sebuah cara bagi pemerintahaan untuk menggunakan sebuah teknologi baru untuk melayani masyarakat dengan memberikan kemudahaan akses untuk pemerintah dalam hal pelayanan dan informasi dan juga untuk menambah kualitas pelayanan serta memberikan peluang untuk berpartisipasi dalam proses dan institusi demokrasi. Tujuan utama $e$ government, yaitu peningkatan efisiensi, kenyamanan, serta aksesibilitas yang lebih baik. Terdapat beberapa jenis e-government salah satunya adalah Government to Citizen/Government to Customer (G2C).

\section{Government to Citizen/Government} to Customer $(G 2 C)$, yaitu pemerintah membangun dan menerapkan berbagai portofolio teknologi informasi dengan tujuan utama untuk memperbaiki hubungan interaksi dengan masyarakat. Dengan kata lain, tujuan utama dari dibangunnya aplikasi e-government bertipe $G$-to- $C$ adalah untuk mendekatkan pemerintah dengan rakyatnya melalui kanal-kanal akses yang beragam agar masyarakat dapat dengan mudah menjangkau pemerintahnya untuk pemenuhan berbagai kebutuhan pelayanan sehari-hari. Government to Citizen adalah penyampaian layanan publik dan informasi satu arah oleh pemerintah ke masyarakat.

Salah satu kota yang menerapkan $e$ government dan menerapkan salah satu jenis dari e-government, yaitu Government to Citizen/Government to Customer (G2C) adalah Kota Bandung dengan website Kota Bandung. Sehingga penyampaian informasi dari Pemerintah Kota Bandung kepada Masyarakat dapat tersampaikan dengan 
baik. Namun, kenyataannya penyampaian informasi tersebut tidak efektif. Hal tersebut terbukti dari banyaknya informasi yang tidak diketahui oleh masyarakat Kota Bandung.

$$
\text { Banyaknya informasi dari }
$$

Pemerintah yang tidak tersampaikan tersebut bertentangan dengan Undang-Undang Dasar 1945 Pasal 28F bahwa "Setiap orang berhak untuk berkomunikasi dan memperoleh informasi untuk pengembangan pribadi dan lingkungan sosialnya, serta berhak untuk mencari, memperoleh, memiliki, menyimpan, mengolah, dan menyampaikan informasi dengan menggunakan segala jenis saluran yang tersedia". Masalah tidak tersampaikannya informasi melalui website itu pula yang menyebabkan Kota Bandung menduduki peringkat ke-4 di Jawa Barat untuk pelayanan e-government di Indonesia.

Ketidakefektifan penyampaian
informasi melalui website resmi Kota
Bandung tersebut diperkuat dari suatu
penelitian yang ditulis dalam sebuah karya
ilmiah yang berjudul "Efeketivitas E-
Government melalui Banserv Pada Kota
Bandung". Kemudian didukung dengan
salah satu solusi yang dapat meningkatkan
efektivitas e-government di Kota Bandung.

\section{Rumusan Masalah}

Berdasarkan latar belakang masalah tersebut dapat dirumuskan masalah, yaitu bagaimana cara untuk meningkatkan efektivitas website resmi Kota Bandung dalam mengoptimalkan program $e$ government?

\section{Tujuan}

Berdasarkan rumusan masalah tersebut tujuan dari penelitian dan penulisan karya ilmiah ini, yaitu untuk mengetahui cara meningkatkan efektivitas website resmi Kota Bandung dalam mengoptimalkan program e-government.

\section{TINJAUAN PUSTAKA}

\section{E-Government}

Menurut Prasojo, E-government, yang dapat didefinisikan sebagai seluruh tindakan dalam sektor publik (baik pusat maupun daerah) yang melibatkan teknologi informasi dan komunikasi dengan tujuan mengoptimalkan proses pelayanan publik 
yang efisien, transparan, dan efektif. Pentingnya e-government paling tidak disebabkan oleh 3 (tiga) faktor, yaitu:

1. Komunikasi elektronik antara sektor publik dan masyarakat menawarkan bagi keduanya bentuk baru untuk partisipasi dan interaksi.

2. Ruang cyber dalam pelayanan publik memudahkan penghapusan struktur birokrasi dan proses klasik dari pelayanan yang berbelit-belit;

3. E-government dapat menawarkan juga informasi di tingkat lokal3.

Dapat dipahami bahwa e-government yang didefinisikan oleh Prasojo adalah tindakan dalam sektor publik yang melibatkan teknologi. Pentingnya implementasi e-government disebabkan oleh beberapa faktor, yaitu penawaran bentuk baru untuk partisipasi dan interaksi, memudahkan proses pelayanan yang cenderung berbelit-belit, dan menawarkan informasi tingkat lokal.

\section{E-government merujuk kepada} penggunaan teknologi khususnya internet dan teknologi komunikasi serta world wide web $(w w w)$ dalam menyelenggarakan pelayanan pemerintah secara elektronik kepada mayarakat, dunia usaha, organisasi, dan lainnya. Dahulu penggunaan $e$ - government masih sebatas percobaan akan tetapi saat ini justru sebagai sarana terpenting dalam transformasi pelayanan di sektor publik. Maka, pemerintahan pada zaman milenial ini harus merujuk pada penggunaan teknologi khususnya internet dan teknologi komunikasi untuk melakukan pelayanan pada masyarakat. Sehingga pemerintahan di Indonesia mengikuti perkembangan zaman.

E-government juga dikaitkan dengan konsep digital e-government atau online $e$ government, dan biasanya dibahas dalam konteks transformational e-government, yaitu penggunaan teknologi internet yang diharapkan dapat menjadi wahana dalam proses pertukaran informasi, menyediakan sarana layanan dan kegiatan transaksi dengan masyarakat, pelaku bisnis dan pihak pemerintah sendiri. Dalam hal ini yang lebih diutamakan adalah konsep transformasinya, dimana e-government bukan sekedar memanfaatkan teknologi semata, melainkan adanya sistem pembuatan kebijakan dan pelayanan publik ke arah yang lebih baik. Oleh karena itu, dapat dipahami bahwa konsep digital e-government adalah penggunaan teknologi yang menjadi wadah untuk kegiatan komunikasi dengan masyarakat. 
Pengertian lain, menurut Hartono, Electronic government merupakan suatu proses sistem pemerintahan dengan memanfaatkan ICT (information, communication and technology) sebagai alat untuk memberikan kemudahan proses komunikasi dan transaksi kepada warga masyarakat, organisasi bisnis dan antara lembaga pemerintah serta stafnya. Sehingga dapat dicapai efisiensi, efektivitas, transparansi dan pertanggungjawaban pemerintah kepada masyarakatnya. Dengan konsep pengembangan menyangkut hubungan Government to Government $(G 2 G)$, Government to Business $(G 2 B)$ dan Government to Citizen (G2C). Lain halnya menurut Hartono, yang menegaskan bahwa e-government adalah pemanfaatan ICT (information, communication and technology) sebagai sarana untuk berkomunikasi dan bertransaksi dengan masyarakat untuk mencapai tujuan, yaitu efisiensi, efektivitas, transparansi, dan pertanggungjawaban pemerintah.

Selain itu, terdapat model $e$ government berdasarkan jenis interaksi antara stakeholder, yaitu Pemerintah ke Masyarakat $(G 2 C)$ berupa penyampaian layanan publik dan informasi satu arah oleh pemerintah ke masyarakat; Masyarakat ke Pemerintah $(C 2 G)$, yaitu memungkinkan pertukaran informasi dan komunikasi antara masyarakat dan pemerintah; Pemerintah ke bisnis $(G 2 B)$, yaitu terdiri dari transaksitransaksi elektronik dimana pemerintah menyediakan berbagai informasi yang dibutuhkan bagi kalangan bisnis untuk bertransaksi dengan pemerintah; Bisnis ke pemerintah $(B 2 G)$, yaitu mengarah kepada pemasaran produk dan jasa ke pemerintah untuk membantu pemerintah menjadi lebih efisien melalui misalnya, peningkatan proses bisnis dan manajemen data elektronik; Pemerintah ke pegawai $(G 2 E)$, yaitu terdiri dari inisiatif-inisiatif yang memfasilitasi manajemen pelayanan dan komunikasi internal dengan pegawai pemerintahan; Pemerintah ke pemerintah $(G 2 G)$, yaitu memungkinkan komunikasi dan pertukaran informasi online antar departemen atau lembaga pemerintahan melalui basis data terintegrasi; Pemerintah ke organisasi nirlaba $(G 2 N), \quad$ yaitu Pemerintah menyediakan informasi bagi organisasi nirlaba, partai politik, atau organisasi sosial; Organisasi nirlaba ke pemerintah (N2G), yaitu memungkinkan pertukaran informasi dan komunikasi antara pemerintah dan organisasi nirlaba, partai politik dan organisasi sosial.

Maka, dapat dipahami bahwa $e$ government merupakan penggunaan 
teknologi oleh pemerintah dalam melaksanakan pelayanan publik. Pada $e$ government terdapat konsep-konsep yang menyangkut hubungan secara garis besar, yaitu hubungan Government to Government $(G 2 G)$, Government to Business (G2B) dan Government to Citizen (G2C).

\section{Government to Citizen (G2C)}

Layanan $G 2 C$ mencakup penyebaran informasi kepada publik serta layanan dasar masyarakat. Layanan $G 2 C$ elektronik atau yang berbasis TIK ditandai dengan sebuah sistem pertukaran informasi pemerintah dan aplikasi-aplikasi berbasis internet yang memungkinkan masyarakat untuk mengakses informasi dan layanan lainnya dengan menggunakan sebuah portal online yang single window. Portal seperti itu menyediakan layanan-layanan masyarakat seperti:

1. Pemrosesan dan penerbitan berbagai surat izin/perizinan dan sertifikat.

2. Informasi terhadap hal-hal legislatif/administratif dan hukumhukum yang berkaitan.

3. Jasa pembayaran, termasuk pajak dan pembayaran iuran sosial.

4. Kesempatan untuk berpartisipasi dalam administrasi pemerintahan melalui permintaan pendapat publik dan pemungutan suara elektronik.

Untuk mendirikan sebuah portal masyarakat dan sistem pertukaran informasi publik, basis data penduduk, real estate, kendaraan, pajak, dan asuransi perlu diintegrasikan. Pada definisi ini, $G 2 C$ adalah suatu layanan penyampaian informasi kepada masyarakat menggunakan sebuah portal single window yang dapat menyediakan berbagai kebutuhan untuk masyarakat.

Government to Citizen (G2C) merupakan aplikasi e-government yang paling umum, yaitu dimana pemerintah membangun dan menerapkan berbagai portofolio teknologi informasi dengan tujuan utama untuk memperbaiki hubungan interaksi dengan masyarakat (rakyat). Dengan kata lain, tujuan utama dari dibangunnya aplikasi e-government bertipe $G$-to- $C$ adalah untuk mendekatkan pemerintah dengan rakyatnya melalui kanalkanal akses yang beragam agar masyarakat dapat dengan mudah menjangkau pemerintahnya untuk pemenuhan berbagai kebutuhan pelayanan sehari-hari. Kanalkanal yang dimaksud pada definisi tersebut contohnya adalah adanya website yang merupakan suatu portofolio teknologi 
informasi yang sering digunakan pemerintah untuk melakukan interaksi dengan masyarakat.

$$
\text { G2C dan } C 2 G \text { memberikan }
$$

informasi yang diminta oleh masyarakat mengenai pajak, lisensi bisnis, pendaftaran, hukum, program pemerintah, dll. Informasi yang diberikan berkaitan pula mengenai proses administratif dan produk; melakukan komunikasi dengan politikus, pemberi informasi, dll. Informasi yang disampaikan bukan hanya sekedar berita saja, namun terdapat informasi yang berguna untuk masyarakat untuk melakukan proses administratif.

Sehingga dapat diketahui bahwa konsep dari model Government to Citizen $(G 2 C)$, yaitu pemerintah menyediakan wadah melalui teknologi seperti website untuk menyampaikan informasi kepada masyarakat. Sehingga, masyarakat dapat mengetahui mengenai informasi yang disampaikan oleh Pemerintah dengan efektif dan efisien.

\section{Website}

Website adalah kesuluruhan halaman-halaman web yang terdapat dalam sebuah domain yang mengandung informasi. Sebuah website biasanya dibangun atas banyak halaman web yang saling berhubungan. Selain itu, website dipahami sebagai media penyampai informasi di internet. Macamnya, bisa sebagai penyedia informasi komersial, service, dan penyampai berita. Maka, website adalah sebuah media elektronik penyampai informasi yang diakses melalui internet, sehingga memudahkan masyarakat untuk mengaksesnya.

Dalam e-government, website memiliki peranan sangat penting. Hal tersebut diketahui dari tingkatan $e$ government menurut Inpres 3/2003, yaitu:

- Tingkat 1 : Persiapan, meliputi pembuatan situs informasi di setiap lembaga, penyiapan SDM, penyiapan sarana akses yang mudah, misalnya Warnet dll.

- Tingkat 2 : Pematangan, meliputi pembuatan situs informasi public interaktif dan pembuatan antar muka keterhubungan dengan lembaga lain.

- Tingkat 3 : Pemantapan, meliputi pembuatan situs transaksi pelayanan public dan pembuatan interoperabilitas aplikasi dan data dengan lembaga lain 2.

- Tingkat 4 : Pemanfaatan, meliputi pembuatan aplikasi untuk pelayanan 
yang bersifat $G 2 G$ (interagency relationship), G2B (Government to Business) dan G2C (Government to Citizen) yang terintegrasi.

Maka, dalam pembuatan website untuk pelayanan publik harus sesuai dengan Undang-Undang yang telah ditetapkan. Menurut panduan dari KOMINFO (2003), isi minimal pada setiap situs web pemerintah daerah :

1. Selayang Pandang. Menjelaskan secara singkat tentang keberadaaan Pemda bersangkutan (sejarah, moto, lambang dan arti lambang, lokasi dalam bentuk peta, visi dan misi).

2. Pemerintahan Daerah. Menjelaskan struktur organisasi yang ada di Pemda bersangkutan (eksekutif, legislative) beserta nama, alamat, telepon, email dari pejabat daerah. Jika memungkinkan biodata dari pimpinan daerah ditampilkan agar masyarakat luas mengetahuinya.

3. Geografi. Menjelaskan antara lain keadaan topografi, demografi, cuaca dan iklim, social dan ekonomi, budaya dari daerah bersangkutan. Semua data dalam bentuk numeric atau statistic harus mencantumkan nama instansi dari sumber datanya.
4. Peta Wilayah dan Sumber daya. Menyajikan batas administrasi wilayah dalam bentuk peta wilayah dan juga sumber daya yang dimiliki oleh daerah bersangkutan dalam bentuk peta sumber daya (dikeluarkan oleh instansi pemda yang mempunyai tugas pokok dan fungsi pembuat peta) yang dapat digunakan untuk keperluan pengguna.

5. Peraturan/Kebijakan Daerah. Menjelaskan peraturan daerah (perda) yang telah dikeluarkan oleh pemerintah daerah bersangkutan. Melalui situs web pemerintah daerah ini semua perda yang dikeluarkan disosialisasikan kepada masyarakat luas.

6. Buku Tamu. Tempat untuk menerima masukan dari pengguna situs web pemda bersangkutan. Sehingga, website yang telah tersedia sebagai media penyampaian informasi dari Pemerintah kepada Masyarakat dapat digunakan dengan mudah oleh Masyarakat. Maka, website yang efektif dan efisien sebagai salah satu media pendukung dapat memberikan 
dampak untuk terwujudnya program e-government yang baik. bentuk tabel atau diagram dan deskripsi. Sehingga hasil penelitian dan analisis data dapat mudah dipahami.

\section{PEMBAHASAN}

\section{Hasil Penelitian}

\section{Hasil Penelitian melalui Google Form}

Berikut hasil penelitian yang telah dilakukan pada bulan Agustus 2017, kepada 110 orang responden masyarakat Kota Bandung. Penelitian dilakukan dengan menyebarkan angket melalui google form.

\section{Alat Pengumpulan Data}

Data dikumpulkan dengan menggunakan angket. Angket sebagai pengumpulan data primer disebar melalui google form kepada masyarakat yang tersebar di Kota Bandung sebanyak 110 orang yang berisi pertanyaan-pertanyaan mengenai pandangan responden terhadap $e$ government di Kota Bandung.

\section{Teknis Analisis Data}

Penelitian ini dilakukan dengan cara menyebar angket melalui google form kepada masyarakat Kota Bandung. Setelah data terambil, dilakukan analisis data. Data yang sudah diperoleh akan diolah sedemikian rupa dan menyajikannya dalam
Grafik 1. Pengetahuan Masyarakat Mengenai Website Resmi Kota Bandung

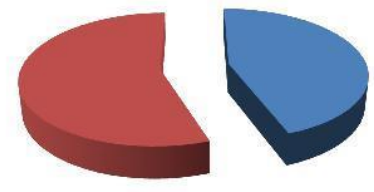

Tidak 56\%

Ya $44 \%$
Grafik 1 menunjukkan pengetahuan masyarakat mengenai website resmi Kota Bandung. Hasil tersebut menunjukkan bahwa sebanyak 48 orang (44\%) mengetahui website resmi Kota Bandung dan 62 orang $(56 \%)$ tidak mengetahui 
website resmi Kota Bandung. Hasil tersebut menunjukkan bahwa penggunaan website oleh masyarakat Kota Bandung belum maksimal. Sehingga pengetahuan masyarakat terhadap website resmi Kota Bandung masih tergolong rendah. Rendahnya pengetahuan masyarakat tersebut menunjukkan bahwa adanya website resmi Kota Bandung masih belum dapat dimanfaatkan oleh masyarakat dengan baik.

Grafik 2. Masyarakat Membuka Website Resmi Kota Bandung

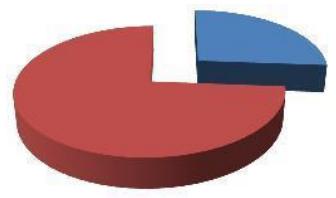

Tidak $74 \%$

Ya 26\%

Sumber: Olahan Peneliti

Grafik 2 mengenai seberapa banyak masyarakat yang suka membuka website resmi Kota Bandung. Pada grafik ini dihitung dari responden yang mengetahui website resmi Kota Bandung. Hasil penelitian menunjukkan bahwa dari 48 orang masyarakat yang mengetahui website resmi Kota Bandung, hanya 12 orang (26\%) saja yang suka membuka website Kota Bandung dan sebanyak 36 orang (74\%) hanya sekedar mengetahui saja. Hal tersebut membuktikan bahwa ketertarikan masyarakat untuk mencari informasi yang dibutuhkan melalui website sangat rendah. Padahal didalam website resmi disediakan banyak informasi yang penting bagi masyarakat.

Rendahnya ketertarikan masyarakat terhadap website resmi Kota Bandung menyebabkan akan terhambatnya penyampaian informasi yang lebih lengkap. Sehingga, masyarakat Kota Bandung kurang memahami informasi yang disampaikan oleh Pemerintah.

Grafik 3. Waktu Masyarakat Membuka Website Resmi Kota Bandung

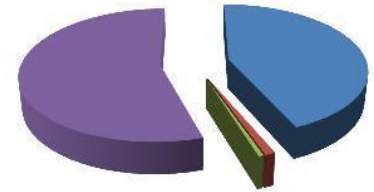

Jarang 55\% Kadang-Kadang 44\%

Setiap Hari 0\% Sering 1\%

Sumber: Olahan Peneliti

Grafik 3 menunjukkan hasil penelitian mengenai waktu responden dalam membuka website. Pertanyaan ini dijawab oleh responden yang menyatakan mengetahui website resmi Kota Bandung. Dari 48 orang yang mengetahui website 
resmi Kota Bandung, hanya 1 orang (1\%) saja yang sering membuka website resmi ini, sebanyak 21 orang (44\%) kadang-kadang, dan sebanyak 26 orang (55\%) jarang sekali membuka website. Hasil tersebut menunjukkan bahwa sebagian besar masyarakat kurang mendapatkan informasi yang resmi dikeluarkan oleh Pemerintah Kota Bandung melalui website resmi yang telah disediakan.

Pemerintah Kota Bandung dapat online di website resmi tersebut setiap hari, kemudian memberikan informasi mulai dari berita serta informasi lainnya. Sehingga informasi yang diberikan selalu update. Tetapi, informasi tersebut akan tidak efektif diberikan apabila masyarakat tidak rajin membuka website resmi Kota Bandung.

\section{Grafik 4. Kelengkapan Informasi Website} Resmi Kota Bandung

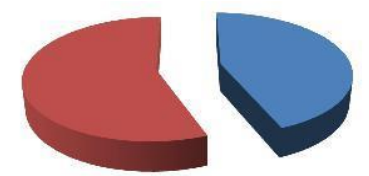

Tidak 56\% Ya 44\%

Sumber: Olahan Peneliti

Grafik 4 mengenai kelengkapan informasi yang disediakan dalam website resmi Kota Bandung. Dari responden yang mengetahui website resmi Kota Bandung, yaitu sebanyak 48 orang. Sebanyak 21 orang (44\%) saja yang mengatakan lengkap dan sebanyak 27 orang (56\%) mengatakan tidak lengkap. Hal tersebut menunjukkan bahwa masih banyak masyarakat yang merasa bahwa dalam website resmi Kota Bandung masih kurang lengkap.

Adanya persepsi masyarakat mengenai ketidaklengkapan tersebut dapat menyebabkan timbulnya ketidaktarikan masyarakat dalam mengakses website resmi Kota Bandung. Kelengkapan didalam website resmi Kota Bandung dapat menjadi acuan bagi masyarakat untuk mendapatkan informasi yang dibutuhkan. Sehingga masyarakat akan lebih tertarik untuk mengakses website resmi Kota Bandung untuk mendapatkan berita baru maupun informasi penting yang menyangkut urusan pemerintahan dengan masyarakat.

Maka, ketidaklengkapan konten didalam website resmi Kota Bandung menurut presepsi masyarakat ini dapat menjadi masalah. Hal tersebut karena konten merupakan unsur penting dalam penyampaian informasi. 
Grafik 5. Website Resmi Kota Bandung Membantu Masyarakat

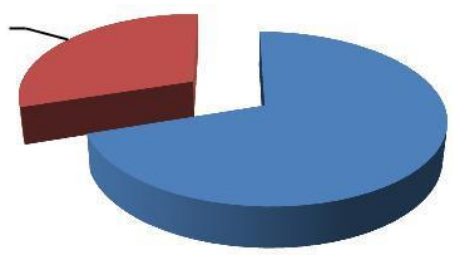

Tidak $30 \%$

Ya $70 \%$

Sumber: Olahan Peneliti

Grafik 5 mengenai keberadaan website dapat membantu masyarakat dalam mendapatkan informasi. Sebanyak 77 orang (70\%) sangat membantu dan sebanyak 33 orang $(30 \%)$ mengatakan tidak membantu sama sekali. Dalam grafik ini menunjukkan bahwa keberadaan website sangat dibutuhkan oleh masyarakat.

$$
\text { Penyediaan website resmi }
$$
merupakan unsur yang penting bagi Pemerintah. Hal tersebut karena website resmi menjadi platform atau tempat bagi pemerintah untuk memberikan informasi mengenai layanan, berita yang terjadi di Kota Bandung, serta informasi lainnya. Sehingga masyarakat dapat mudah mengakses dan mengetahui informasi yang lebih valid untuk digunakan dalam kehidupan bermasyarakat, karena informasi didalam website resmi ditulis langsung oleh Pemerintah yang bersangkutan.

\section{Analisis website resmi Kota Bandung}

Menurut KOMINFO, dalam website resmi minimal terdapat konten, yaitu:

1. Selayang Pandang, meliputi sejarah, moto, lambang dan arti lambang, lokasi dalam bentuk peta, visi dan misi. Pada website resmi Kota Bandung tidak tersedia lokasi dalam bentuk peta. Sedangkan, lokasi dalam bentuk peta sangat membantu masyarakat dalam menemukan lokasi yang tepat. Lokasi dalam bentuk peta sangat dibutuhkan karena dapat mudah diakses melalui internet oleh masyarakat dalam skala berapapun.

2. Pemerintahan Daerah, yang meliputi anggota struktural dari Pemerintah Kota Bandung. Dalam website resmi Kota Bandung konten ini sudah lengkap tersedia. Sehingga masyarakat dapat mudah mengetahui struktural pemerintah yang bertugas melayaninya.

3. Geografi, meliputi penjelasan keadaan topografi, demografi, cuaca dan iklim, social dan ekonomi, budaya dari daerah bersangkutan. 
Akan tetapi, pada website resmi Kota Bandung keadaan topografi tidak tersedia serta tampilan di website yang mencantumkan keadaan geografi masih terdapat beberapa yang tidak bisa diakses.

Keadaan topografi sangat penting untuk memberikan informasi kepada masyarakat mengenai daerah-daerah yang aksesnya dapat mudah dilalui dan tidak dapat dengan mudah dilalui. Selain itu, adanya kesalahan teknis pada konten yang tidak dapat diakses dapat mengahambat masyarakat dalam mendapatkan informasi. Sehingga masyarakat tidak tertarik untuk mengakses website yang telah disediakan oleh Pemerintah.

4. Peta Wilayah dan Sumber daya, dalam website resmi Kota Bandung tidak tersedia peta wilayah dan tidak ada penyajian sumber daya dalam bentuk peta. Ketidaktersediaan konten ini dapat memberikan presepsi yang negatif kepada masyarakat. Hal tersebut karena masyarakat perlu mengetahui sumber daya yang dimiliki Kota Bandung. Sehingga apabila terdapat masyarakat yang akan memanfaatkan sumber daya yang tersedia dapat dengan mudah mengetahui jumlah kekayaan sumber daya yang dimiliki oleh Kota Bandung.

5. Peraturan/Kebijakan Daerah, Pemerintah Kota Bandung telah menyampaikan Peraturan/Kebijakan Daerah pada website resmi yang disediakan. Sehingga masyarakat dapat mengakses dengan mudah, mengetahui, serta memahami peraturan/kebijakan yang berlaku di Kota Bandung. Sehingga masyarakat dapat mengimplementasikannya dengan baik.

6. Buku Tamu, sudah tersedia dalam bentuk/nama, yaitu pengaduan. Dengan adanya buku tamu ini dalam bentuk kotak pengaduan ini dapat memudahkan masyarakat dalam menyampaikan saran dan pengaduannya. Sehingga masukan dan pengaduan dari masyarakat tersebut dapat langsung tersampaikan kepada Pemerintah.

Dari hasil analisis tersebut dapat diketahui bahwa website resmi Kota Bandung masih belum lengkap dan masih terdapat beberapa konten yang tidak bisa diakses, hal tersebut sesuai dengan hasil 
penelitian yang telah dilakukan. Selain itu, pengunjung website resmi Kota Bandung masih sangat rendah dibanding dengan banyaknya jumlah masyarakat Kota Bandung. Hal tersebut mendukung hasil penelitian bahwa website resmi Kota Bandung masih belum efektif dalam penyampaian informasi kepada masyarakat. Sehingga masyarakat tidak mendapatkan informasi dengan jelas dan lengkap.

Maka, dari hasil penelitian yang telah dilakukan, dapat diketahui masalah $e$ government pada model G2C (Government to Citizen) di Kota Bandung, yaitu pertama, kurangnya pengetahuan masyarakat mengenai website resmi Kota Bandung, kedua, kurangnya informasi yang didapatkan oleh masyarakat, karena masyrakat jarang sekali mengakses website, ketiga, informasi yang disediakan dalam website resmi Kota Bandung masih dianggap kurang lengkap. Oleh karena itu, diperlukan suatu alternatif solusi untuk mendukung penyampaian informasi kepada masyarakat melalui website, dengan lebih lengkap, tepat, cepat dan efektif. Salah satu alternatif solusi yang dapat digunakan untuk menyelesaikan permasalahan tersebut adalah melalui Banserv.

\section{Solusi}

Banserv (Bandung Service) adalah salah satu layanan yang digunakan untuk menyampaikan informasi kepada masyarakat. Banserv (Bandung Service) merupakan suatu layanan notifikasi yang dapat muncul pada handphone masyarakat Kota Bandung. Notifikasi tersebut berupa pemberitahuan yang muncul pada handphone masyarakat Kota Bandung apabila ada informasi yang di upload dalam website resmi pemerintah Kota Bandung. Pemberitahuan tersebut berupa pesan singkat (SMS) yang di dalamnya terdapat penjelasan mengenai informasi yang di upload oleh pemerintah dan terdapat link yang dapat langsung terhubung dengan website resmi Kota Bandung.

Pemberitahuan melalui pesan singkat (SMS) dapat memudahkan masyarakat untu mengakses secara langsung. Hal tersebut karena dengan penyampaian mealui pesan singkat dapat diterima oleh masyarakat yang menggunakan jenis telpon genggam manapun. Sehingga informasi pemerintah dapat tersampaikan dengan mudah dan masyarakat Kota Bandung dapat langsung mengakses informasi tersebut.

Banserv (Bandung Service) dapat terealisasi dengan bantuan dari Dinas 
Komunikasi dan Informatika (KOMINFO)

Kota Bandung dan operator-operator yang dapat mendukung untuk menyebarkan informasi. Adanya sinergitas antara Dinas Komunikasi dan Informatika (KOMINFO) dengan operator-operator ini untuk mendapatkan kontak masyarakat Kota Bandung yang sudah terdaftar pada jaringan di wilayah Kota Bandung. Alternatif solusi menggunakan Banserv ini memiliki konsep seperti yang dilakukan oleh BMKG dengan bantuan KOMINFO dalam memberi peringatan kepada masyarakat mengenai bencana. Konsep yang dilakukan memberikan dampak yang signifikan kepada masyarakat, sehingga masyarakat lebih mengetahui dengan cepat dan tepat. Artinya, apabila terdapat informasi atau berita baru yang terbit di website resmi Kota Bandung, dengan otomatis terdapat pesan singkat yang diterima oleh masyarakat beserta link yang dapat menghubungkan pada website resmi. Sehingga masyarakat dapat langsung mengaksesnya dan mendapatkan informasi dengan lebih cepat. Oleh karena itu, alternatif solusi menggunakan layanan Banserv ini dapat membantu masyarakat dengan mudah untuk mengakses website dan mendapatkan informasi

Selain itu, untuk Pemerintah Kota Bandung disarankan untuk lebih melengkapkan kembali informasi yang disediakan dalam website yang masih dianggap kurang lengkap oleh masyarakat, karena konten-konten dalam website resmi sangat dibutuhkan oleh masyarakat dalam mendapatkan informasi yang lengkap dan valid. Sehingga, kebutuhan masyarakat mengenai informasi dapat terpenuhi dengan baik.

Maka, alternatif solusi melalui Banserv (Bandung Service) dapat membantu permasalahan, yaitu pengetahuan masyarakat mengenai website resmi Kota Bandung, kurangnya informasi yang didapatkan oleh masyarakat karena jarangnya masyarakat membuka website, dan kurang lengkapnya informasi dalam website dapat terselesaikan. Sehingga model Government to Citizen pada e-government di Kota Bandung dapat berjalan dengan baik.

\section{PENUTUP}

\section{Kesimpulan}

Kota Bandung merupakan salah satu daerah yang menerapkan program $e$ government di Indonesia, salah satu jenis $e$ government adalah Government to Citizen/Government to Customer (G2C). Government to Citizen/Government to 
Customer (G2C), yaitu pemerintah membangun dan menerapkan berbagai portofolio teknologi informasi dengan tujuan utama untuk memperbaiki hubungan interaksi dengan masyarakat. Dengan kata lain, tujuan utama dari dibangunnya aplikasi e-government bertipe Government to Citizen (G-to-C) adalah untuk mendekatkan pemerintah dengan rakyatnya melalui kanalkanal akses yang beragam agar masyarakat dapat dengan mudah menjangkau pemerintahnya untuk pemenuhan berbagai kebutuhan pelayanan sehari-hari. Government to Citizen (G2C), yaitu pemerintah menyediakan wadah melalui teknologi seperti website untuk menyampaikan informasi kepada masyarakat. Sehingga, masyarakat dapat mengetahui mengenai informasi yang disampaikan oleh Pemerintah dengan efektif dan efisien. Namun, kenyataannya penyampaian informasi tersebut tidak efektif. Hal tersebut terbukti dari banyaknya informasi yang tidak diketahui oleh masyarakat Kota Bandung.

$$
\text { Banyaknya informasi dari }
$$

Pemerintah yang tidak tersampaikan tersebut bertentangan dengan Undang-Undang Dasar 1945 Pasal 28F. Masalah tidak tersampaikannya informasi melalui website itu pula yang menyebabkan Kota Bandung menduduki peringkat ke-4 di Jawa Barat untuk pelayanan e-government di Indonesia.

Ketidakefektifan penyampaian informasi melalui website resmi Kota Bandung tersebut diperkuat dari suatu penelitian yang dilakukan dengan cara menyebarkan angket melalui google form kepada 110 orang masyarakat Kota Bandung. Hasil penelitian yang telah dilakukan diolah menggunakan metode kuantitatif. Hasil tersebut membuktikan bahwa permasalahan e-government di Kota Bandung, yaitu pertama, kurangnya pengetahuan masyarakat mengenai website resmi Kota Bandung, kedua, kurangnya informasi yang didapatkan oleh masyarakat, karena masyarakat jarang sekali mengakses website, ketiga, informasi yang disediakan dalam website resmi Kota Bandung masih dianggap kurang lengkap.

Untuk menyelesaikan permasalahan tersebut, diperlukan suatu alternatif solusi, yaitu melalui Banserv (Bandung Service), yaitu salah satu layanan yang digunakan untuk menyampaikan informasi kepada masyarakat. Banserv (Bandung Service) merupakan suatu layanan notifikasi yang dapat muncul pada handphone masyarakat Kota Bandung. Layanan notifikasi Banserv (Bandung Service) ini dapat terealisasi 
dengan bantuan dari Dinas Komunikasi dan Informatika Kota Bandung. Sehingga model Government to Citizen pada e-government di Kota Bandung dapat berjalan dengan baik.

\section{Saran}

Untuk Pemerintah disarankan agar mengoptimalkan infromasi yang disediakan dalam website. Sehingga masyarakat dapat mengakses informasi lebih lengkap. Serta Pemerintah mendukung dengan adanya solusi yang telah disediakan agar hubungan Pemerintah dengan masyarakat dalam penyampaian informasi dapat berjalan dengan baik.

Untuk Masyarakat disarankan agar tidak selalu mengabaikan informasi yang telah disampaikan oleh Pemerintah. Serta masyarakat dapat mendukung adanya solusi ini. Sehingga informasi dapat diterima langsung dan tidak tertinggal informasi yang telah disampaikan.

\section{DAFTAR PUSTAKA}

Wahyuningtyas,C,E, 2017,

Keterkaitan

Penerapan E-Government dengan Pola Perekrutan Perangkat Desa, Web
Unair, Diakses pada Sabtu, 23 September 2017, <http://christianaeka-wahyuningsih-

fisip15.web.unair.ac.id/artikel_detail -173377-TUGAS-

Keterkaitan\%20Penerapan\%20EGov ernment \%20dengan\%20Pola\%20Per $\mathrm{e}$ krutan\%20Perangkat\%20Desa.html>

Direktorat e-government, 2015, Tabel

Hasil PeGI Tahun 2015 Tingkat Jawa Barat, Jakarta, Direktorat Jenderal Aplikasi Informatika, Kementerian Informasi dan Komunikasi RI, Diakses Pada Selasa, 12 September 2017, <http://pegi.layanan.go.id/download/ tabel_pegi_2015/2015_KAB_KOTA _JAWABARAT.PNG.>

Darmawan.I, 2011, E-government:

Studi Pendahuluan Di Kabupaten Sragen. Serang, Proceeding Simposium Nasional Otonomi Daerah 2011 ISBN: 978-602-968482-77 LAB-ANE FISIP Untirta

Hardjaloka.L, 2014, Studi Penerapan E-Government di Indonesia dan Negara Lainnya Sebagai Solusi 
Pemberantasan Korupsi di Sektor

Publik. Jakarta, Jurnal Rechts

Vinding Media Pembinaan Hukum

Nasional

Jaya.S, 2014, Implementasi dan

Perkembangan E-Government di Indonesia, Diakses Pada Rabu, 13 September 2017

$<$ http://jim.stimednp.ac.id/wpcontent/uploads/2014/03/IMPLEME

NTASI-DAN-PERKEMBANGANE-GOVERNMENT.pdf>

Sitokdana.M.N.N, 2015, Evaluasi

Implementasi eGovernment Pada

Situs Web Pemerintah Kota Surabaya, Medan, Banjarmasin, Makassar dan Jayapura, Yogyakarta, Pascasarjana Teknik Elektro, Universitas Gadjah Mada

Lee.N.Y, 2009, Modul 3 Penerapan e Government. Songdo-dong, Yeonsugu, Incheon City Republic of Korea, United Nations Asian and Pacific Training Centre for Information and Communication Technology for Development

Kurniawan.R, 2017, Perkembangan E government di Indonesia, imulti, Diakses Pada Rabu, 13 September 2017, <http://ilmuti.org/wpcontent/uploads/2017/04/Reza-

Kurniawan-perkembangan-E-

government.pdf>

Fang.Z, 2002, E-Government in

Digital Era: Concept, Practice, and Development, Thailand, School of Public Administration, National Institute of Development Administration (NIDA)

Yuhefizar, Mooduto.HA, dkk, 2009, Cara Mudah Membangun Website Interaktif Menggunakan Content Management System Joomia Edisi Revisi, Jakarta, PT. Elex Media Kompotindo

Jovan.FN, tt, Panduan Praktis Membuat Web dengan PHP untuk Pemula, Jakarta, Media Kita

Mulus.R.T, 2009, Analisis

E-Government pada Kabupaten/Kota di Indonesia. Jakarta, Jurusan Teknik Informatika Universitas Gunadarma 